\title{
FORMULATION AND EVALUATION OF MUCOADHESIVE BUCCAL TABLETS CONTAINING IVABRADINE HYDROCHLORIDE BY USING NATURAL POLYMERS
}

\author{
Manoj Kumar Premi ${ }^{1}$, Dr. Manish Kumar Gupta ${ }^{2}$, Bannaruvari Phanindra ${ }^{3}$, Prof. B. Krishnamoorthy ${ }^{4}$ \\ ${ }^{1}$ M.Pharm. Research Scholar, Department of Pharmaceutics, Jaipur College of Pharmacy, Jaipur, \\ Rajasthan, India \\ ${ }^{2}$ Professor and Principal, Jaipur College of Pharmacy, Jaipur, Rajasthan, India \\ ${ }^{3}$ Assistant Professor, Nimra College of Pharmacy, Jupudi, IBM, Andrapradesh \\ ${ }^{4}$ Professor, Sanjivani College of Pharmaceutical Sciences, Rajota, Khetri, Rajasthan
}

Article Info: Received 01 January 2019; Accepted 15 April. 2019

Cite this article as: Premi, M., Gupta, M., \& Phanindra, B. (2019). FORMULATION AND EVALUATION OF MUCOADHESIVE BUCCAL TABLETS CANTANING IVABRADINE HYDROCHLORIDE BY USING NATURAL POLYMERS. Journal of Biomedical and Pharmaceutical Research, 8(2).

DOI: https://doi.org/10.32553/jbpr.v8i2.588

Address for Correspondence: Manoj Premi, M.Pharm. Research Scholar, Department of Pharmaceutics, Jaipur College of Pharmacy, Jaipur, Rajasthan, India

Conflict of interest statement: No conflict of interest

\section{ABSTRACT:}

The buccal mucosa is moderately permeable, strong when match up with the other mucosal tissues and is more tolerant to potential allergens which have a compact affinity to unalterable irritation or harm. Mucoadhesive buccal drug delivery system offers a control release system; it entails the administration of required drug through the buccal mucosal membrane lining of the oral cavity. The Bioadhesive was resulting from the need to limit drugs at a definite site in the body. Significantly at the absorption site, enhance the degree of drug absorption is restricted by the residence time of the drug. The API, blend of excipients and drug were prepared at the ratio of $1: 1$, filled in closed vials and kept in accelerated environmental conditions $\left(40^{\circ} \mathrm{C} / 75 \% \mathrm{RH}\right)$ for a period of 1 month. Excipients were employed here to assess the compatibility issue with the active ingredient. The possible drug and polymer interaction studies were assessed by using FTIR. Calibration curve of ivabradine $\mathrm{HCl}$ was constructed by dissolving pure drug of ivabradine $\mathrm{HCl}(100 \mathrm{mg}$ ) in $100 \mathrm{~mL}$ of phosphate buffer $(\mathrm{pH}$ 6.8) to give $1 \mathrm{mg} / \mathrm{mL}$ concentration and designed as stock solution-1. The angle of repose was determined by fixed funnel method. The prepared mucoadhesive buccal tablets were estimated for post compression factors such as thickness, friability, drug content and hardness. The surface $\mathrm{pH}$ study was conducted on ivabradine $\mathrm{HCl}$ mucoadhesive buccal tablets, carried out to predict the comfort of the buccal formulation into the possibility of any side effects in buccal mucosa environment. F1 and F5 possessed the best results among all the formulations in terms of in vitro release of drug. However, F2 formulation shows highest mucoadhesive and swelling index than other formulation. Therefore, from the data, it may be concluded that F2 formulation might be considered as promising mucoadhesive buccal tablet formulation for a suitable sustained drug delivery system for ivabradine.

Keywords: Ivabradine Hydrochloride, Buccal tablet, Mucoadhesive, Natural Polymers. 


\section{INTRODUCTION:}

The oral administration of pharmaceutical compound has been several troubles such as irregular and variable absorption, GI intolerance, decreased bioavailability; presystemic exclusion has provoked the consideration of other possible route for administration. For example, it is complicated to continue the medicament at the preferred site so that it can be absorbed, distributed and metabolized effortlessly. This restriction leads to the enhancement of other routes of administration $^{[1]}$.

\subsection{Necessitate of Mucoadhesive DDS:}

Buccal mucosa is soft and comparatively stationary surface and is appropriate for the assignment of controlled-release system. The buccal mucosa is moderately permeable, strong when match up with the other mucosal tissues and is more tolerant to potential allergens which have a compact affinity to unalterable irritation or harm.

\subsection{Mucoadhesive Buccal Drug Delivery System}

Mucoadhesive buccal drug delivery system offers a control release system; it entails the administration of required drug through the buccal mucosal membrane lining of the oral cavity. It is very helpful for transmucosal (systemic effect) and mucosal (local effect) drug administration. In the foremost case, involves drug absorption through the mucosal barrier, to attain the systemic circulation whereas the second cases to attain a sitespecific release of the drug on the mucosa ${ }^{[9]}$.

\subsection{Routes of Drug Transport across the buccal mucosa}

The two major mechanisms concerned for the penetration of different substances include passive transmission intra cellular or Trans cellular (crossing through the cell membranes with a lipid domain and a polar) whereas the passive diffusion intercellular or para cellular (passing around between the cells) carrier intervened transport and pinocytosis ${ }^{[12]}$.

\subsection{Classification of permeation enhancers}

- Chelators: Methoxy salicylates, EDTA, sodium salicylate, citric acid ${ }^{[15]}$.

- Surfactants: Polyoxythylene-20-cetylether, polyoxyethylene. sodium lauryl sulphate, Benzalkoniumchloride, Polyoxyethylene-9laurylether,

- Bile salts: sodium tauro cholate, sodium glycocholate, sodium tauro deoxycholate, sodium deoxy cholate.

- $\quad$ Fatty acids: oleic acid, lauric acid, capric acid, phosphatidylcholine, methyl oleate, propylene glycol.

- Inclusion complexes: cyclodextrins.

- Others: azone aprotinin, sulfoxides, polysorbate 80 , dextran sulfate, cyclodextrin, various alkyl glycosides and menthol.

- Thiolated polymers: chitosan-cysteine, chitosan-4-thioglycholic acid, chitosan-4thiobutylamide.

\subsection{Use of Buccal Adhesive Preparations}

The Bioadhesive was resulting from the need to limit drugs at a definite site in the body. Significantly at the absorption site, enhance the degree of drug absorption is restricted by the residence time of the drug. The mucus layer, which covers the epithelial surface, has various roles.

- Protective role

- Barrier role

- Adhesion role

- Lubrication Role

- Marketed products of Mucoadhesive Buccal Dosage Forms 
Manoj Premi et al, Journal of Biomedical and Pharmaceutical Research

Table 1: Mucoadhesive buccal dosage forms (Market available)

\begin{tabular}{|l|l|}
\hline \multicolumn{1}{|c|}{ Drug Name } & Manufacturers Name/Brand name \\
\hline Nitro-glycerine & Glenmark (nitrogard) \\
\hline Miconazole & BioAlliancePharmaSA (loramyc) \\
\hline Methyl testosterone & $\begin{array}{l}\text { Bayer Schering Pharma } \\
\text { (Oreton methyl) }\end{array}$ \\
\hline Hydrocortisone & Auden Mckenzie (corlan pellets) \\
\hline Fentanyl & Cephalon (fentora CII) \\
\hline Insulin buccal delivery & $\begin{array}{l}\text { Shreyalife sciences } \\
\text { (Oral Recosulin) }\end{array}$ \\
\hline Omeprazole & Astrazeneca (Prilosec) \\
\hline Vitamin-C & Zhongnuo (CSPC) \\
\hline Clotrimazole & Lotrimin, Mycelex \\
\hline Testosterone & $\begin{array}{l}\text { Actient pharmaceuticals } \\
\text { (Striant) }\end{array}$ \\
\hline
\end{tabular}

\section{EXPRIMENTAL WORK}

Table 2: Equipments were used for this present work

\begin{tabular}{|l|l|l|l|}
\hline Equipment & Model & Manufacturers & $\begin{array}{l}\text { Manufacturer } \\
\text { Location }\end{array}$ \\
\hline Franz diffusion cells apparatus & EDC-07 & Electro lab & Mumbai, India \\
\hline Tablet pilot press 10 stations & PP-1 & Karnavathi & Ahmadabad,India \\
\hline UV-visible Spectrophotometer & 2602 & Shimadzu & Mumbai, India \\
\hline pH Meter & L1127 & Elico Ltd & Hyderabad, India \\
\hline Friabilitor & EF-2,double drum & Electro lab & Mumbai, India \\
\hline FT-IR Spectroscopy & $8400 S(S h i m a d z u)$ & Shimadzu & Japan \\
\hline Digital balance & CA224 & $\begin{array}{l}\text { LWL Precision } \\
\text { instrument }\end{array}$ & Mumbai, India \\
\hline Hardness tester & Monsanto & $\begin{array}{l}\text { Kshitij } \\
\text { International }\end{array}$ & Haryana, India \\
\hline Hot air oven & i-therm & Jainson & Mumbai, India \\
\hline
\end{tabular}

Table 3: Materials used in this present work

\begin{tabular}{|l|l|}
\hline Material & Source \\
\hline Ivabradine $\mathrm{HCl}$ & The Madras Pharmaceuticals Pvt. Ltd- Chennai \\
\hline Guar gum & ASES Chemical Works, Jodhpur \\
\hline Pectin & CDH Laboratory, New Delhi \\
\hline Chitosan & Cochin foods, Cochin Kerala \\
\hline Ethyl cellulose & CDH Laboratory, New Delhi \\
\hline Magnesium stearate & CDH Laboratory, New Delhi \\
\hline Potassium dihydrogen phosphate & New India chemical Enterprises,Mumbai \\
\hline Disodium hydrogen phosphate & New India chemical Enterprises,Mumbai \\
\hline Lactose anhydrous & Qulaligens Fine Chemicals,Mumbai \\
\hline
\end{tabular}




\subsection{Preformulation studies:}

\subsubsection{Drug-polymer compatibility studies by physical examination}

The API, blend of excipients and drug were prepared at the ratio of $1: 1$, filled in closed vials and kept in accelerated environmental conditions $\left(40^{\circ} \mathrm{C} / 75 \% \mathrm{RH}\right)$ for a period of 1 month.

\subsubsection{Drug-polymer interaction studies by FTIR}

Excipients were employed here to assess the compatibility issue with the active ingredient. The possible drug and polymer interaction studies were assessed by using FTIR (Fourier transform infrared spectroscopy).

\subsubsection{Construction of calibration curve for Ivabradine $\mathrm{HCl}$}

Calibration curve of ivabradine $\mathrm{HCl}$ was constructed by dissolving pure drug of ivabradine $\mathrm{HCl}(100 \mathrm{mg})$ in $100 \mathrm{~mL}$ of phosphate buffer ( $\mathrm{pH}$ 6.8) to give $1 \mathrm{mg} / \mathrm{mL}$ concentration and designed as stock solution-1

2.1.4 Evaluation of pre-compression parameters of sustained release mucoadhesive buccal tablet blends of ivabradine $\mathrm{HCl}$

Precompression evaluation parameters furnish the data's necessary to describe the character of the drug material and offer a outline for the drug grouping with pharmaceutical excipients in the manufacture of a dosage form.

\subsubsection{Measurement of powder flow characteristics}

The angle of repose was determined by fixed funnel method ${ }^{[19]}$. The funnel kept at a altitude of $2.5 \mathrm{~cm}$ from the surface. Samples were poured onto the centre of the dish from a funnel that can be elevated perpendicularly; till it formed a heap is obtained. The radius was calculated and the angle of repose was planned by means of the formula mentioned below. The identical process was repeated for three times and the average value was taken.

$\operatorname{Tan} \theta=h / r$ (or) $\theta=\tan ^{-1}(h / r)$

\subsubsection{Measurement of powder density $(\mathrm{g} / \mathrm{cc})$}

Bulk density refers to a measure used to describe a packing of particles or granules. An precisely weighed amount of a powder (W) which was formerly accepted through sieve number 22 was cautiously poured into a graduated cylinder and the volume (Vo) occupied was calculated ${ }^{[21]}$.

\subsubsection{Measurement of powder compressibility}

Compressibility is a significant measure that can be attained from tapped and bulk densities $^{[104]}$. The fewer compressible a substance the more flow proficient it is. Compressibility index calculated by means of the following formula and expressed in terms of $\%$.

$\mathrm{I}=100\left(D_{\mathrm{t}}-\mathrm{D}_{\mathrm{b}}\right) / \mathrm{D}_{\mathrm{t}}$

\section{EXPERIMENTAL DESIGN}

Formulation design was created to determine and optimize the effect of the three polymers concentration variables.

Table 4: Composition variables of Ivabradine Hydrochloride buccal tablets

\begin{tabular}{|l|l|l|l|l|l|l|l|}
\hline \multicolumn{4}{|l|}{ Drug Reservoir (mg) } & \multicolumn{2}{l|}{ Drug Free Backing Layer (mg) } \\
\hline Formula code & Drug & Guar gum & Chitosan & pectin & Lactose & EC & Mg. Stearate \\
\hline F1 & 5 & 35 & 25 & 20 & 65 & 20 & 10 \\
\hline F2 & 5 & 60 & 25 & 20 & 40 & 20 & 10 \\
\hline F3 & 5 & 35 & 40 & 20 & 50 & 20 & 10 \\
\hline F4 & 5 & 60 & 40 & 20 & 25 & 20 & 10 \\
\hline F5 & 5 & 35 & 25 & 40 & 45 & 20 & 10 \\
\hline
\end{tabular}


Manoj Premi et al, Journal of Biomedical and Pharmaceutical Research

\begin{tabular}{|l|l|l|l|l|l|l|l|}
\hline F6 & 5 & 60 & 25 & 40 & 20 & 20 & 10 \\
\hline F7 & 5 & 35 & 40 & 40 & 10 & 20 & 10 \\
\hline F8 & 5 & 60 & 40 & 40 & 5 & 20 & 10 \\
\hline
\end{tabular}

Each tablet weight is $180 \mathrm{mg}$

\subsection{Evaluation of Post compression parameters of mucoadhesive buccal tablets of Ivabradine $\mathrm{HCl}$ :}

The prepared mucoadhesive buccal tablets were estimated for post compression factors ${ }^{[26]}$ such as thickness, friability, drug content and hardness.

\subsubsection{Thickness}

The thickness of randomly selected average of the five buccal tablets was used from each formulation, resoluted by using screw guage and results were articulated in millimeter.

\subsubsection{Hardness}

Tablets have need of a definite sum of resistance and hardness or strength to resist involuntary shocks of managing in packaging, shipping and manufacture. The rigidity of five tablets randomly selected from each formulation, calculated by means of monsanto hardness tester apparatus and results were and expressed in $\mathrm{Kg} / \mathrm{cm}^{2}$.

\subsubsection{Friability}

Friability test is assessing the strength of the granules; friability test was done by using Roche friability test apparatus was used to conclude the friability of the prepared buccal tablets. Twenty pre-weighed buccal tablets was located in the friabilator apparatus and activated for 100 revolutions (25 rpm) in four minutes and the buccal tablets freed from dust and reweighed. The prescribed limit for loss on friability is not more than $1 \% \mathrm{w} / \mathrm{w}$. The percentage friability was evaluated according to the following formula ${ }^{[27]}$

$\%$ Friability $=$ Pre weight-Final Weight $\quad$ X 100

Pre weight

\subsubsection{Drug content}

Ten prepared buccal tablets were selected randomly from each formulation were delicately powdered and equalivalent weight of $5 \mathrm{mg}$ of ivabradine $\mathrm{HCl}$ powder was exactly weighed and place in to $100 \mathrm{ml}$ volumetric flasks having $50 \mathrm{ml}$ of phosphate buffer $\mathrm{pH} 6.8$. The volumetric flasks were shaken to mix the stuffings carefully. The amount was made up to the mark with phosphate buffer $\mathrm{pH} 6.8$ and filtered. $1 \mathrm{ml}$ of the filtrate with appropriate dilution was calculated for ivabradine $\mathrm{HCl}$ content at $285 \mathrm{~nm}$ by means of a double beam UV-visible spectrophotometer.

\subsubsection{Surface $\mathrm{pH}$ study}

The surface $\mathrm{pH}$ study ${ }^{[28]}$ was conducted on ivabradine $\mathrm{HCl}$ mucoadhesive buccal tablets, carried out to predict the comfort of the buccal formulation into the possibility of any side effects in buccal mucosa environment. The prepared buccal tablet were permissible to distend by maintaining it make contact with $5 \mathrm{ml}$ of phosphate buffer containing $2 \% \mathrm{w} / \mathrm{v}$ agar medium $(\mathrm{pH} 6.8 \pm 0.01)$ at room temperature for $2 \mathrm{hrs}$. The surface $\mathrm{pH}$ was deliberate by keeping the electrode in make contact with the surface of the buccal tablet and permiting it to equilibrate for 1 minute. The mean of three reading was recorded.

\subsection{Swelling index characteristics for buccal tablets}

The swelling index performance study was carried out on ivabradine $\mathrm{HCl}$ buccal tablets. The degree of swelling index was on purpose in terms of \% weight gain ${ }^{[29]}$ by the mucoadhesive buccal tablets. The swelling index velocity of the bioadhesive buccal tablet was estimated by means of $1 \%$ agar gel plate. The initial weight of the buccal tablet was deliberate (W1). The buccal tablet from each formulation was located on gel surface in a petridish 
incubator at $37 \pm 5^{\circ} \mathrm{C}$. The buccal tablets were detached at dissimilar time intervals $(1,2,3,4$, 5 and $6 \mathrm{~h}$ ) and wiped with filter paper and weighed again (W2). The swelling index performance was estimated by the formula.

\section{S.I $=[(\mathrm{W} 2-\mathrm{W} 1) / \mathrm{W} 1] \times 100$}

Where S.I = Swelling Index W1- Initial weight of buccal tablet, W2- weight of swollen buccal tablet at time $(\mathrm{t})$.

\subsection{Measurement of invitro buccoadhesive strength}

Measurement of mucoadhesive strength ${ }^{[24]}$ required breaking the adhesive bond between a buccal membrane and buccal tablets was carried by modifying balance method. Fresh Sheep buccal mucosa was employed as model membrane. Fresh sheep buccal mucosa were acquired from a local slaughter-house and utilized for the study within $2 \mathrm{~h}$ of slaughter.

\subsection{Ex-vivo Drug Permeation through sheep buccal mucosa}

An ex-vivo buccal permeation study ${ }^{[19]} \mid$ vabradine $\mathrm{HCl}$ tablet was carried through the sheep buccal mucosal membrane. The buccal tablet was positioned in such a way that it fixed on the mucous membrane and the compartments clamped together. The receptor compartment was packed with isotonic phosphate buffer $\mathrm{pH}$ 6.8. The assembly was sustained temperature at $37 \pm 5^{\circ} \mathrm{C}$ and stirred with a magnetic bead at $50 \mathrm{rpm}$. Samples were withdrawn and filtered through whatman filter paper; at regular time intervals analyzed by means of UV Spectrophotometer at $285 \mathrm{~nm}$.

\subsection{In-vitro kinetics studies}

The in-vitro release data was fit into kinetic models to explain the release kinetics ${ }^{[26]}$ of ivabradine $\mathrm{HCl}$ from the buccal tablets. The kinetic models used were a zero-order equation, First order kinetics, higuchi's and Korsemeyer- Peppa's models.

\subsection{Stability Studies}

Short term stability study ${ }^{[30]}$ was carried out on the optimized ivabradine $\mathrm{HCl}$ buccal tablets. Adequate number of buccal tablets were filled in amber colored rubber Stoppard bottles and reserve in stability compartment maintained at temperature at $40 \pm 2^{\circ} \mathrm{C} / 75 \pm 5 \% \mathrm{RH}$ for three months were analysed regularly, for their swelling index, physical appearance, buccoadhesive strength, drug content, and invitro drug release. All the datas collected were analysed by using Prism software 5 .

\section{RESULT AND DISCUSSION:}

4.1 Drug-polymer compatibility studies by physical examination

Table 5: Compatibility data for Ivabradine $\mathrm{HCl}$ and excipients

\begin{tabular}{|c|c|c|c|c|c|}
\hline \multirow[b]{2}{*}{ API and Excipients } & \multirow[b]{2}{*}{ Ratio } & $1^{\text {st }}$ Week & $2^{\text {nd }}$ Week & $3^{\text {rd }}$ Week & $4^{\text {th }}$ Week \\
\hline & & $\begin{array}{l}40^{\circ} \mathrm{C} / \\
75 \% \mathrm{RH}\end{array}$ & $\begin{array}{l}40^{\circ} \mathrm{C} / \\
75 \% \mathrm{RH}\end{array}$ & $\begin{array}{l}40^{\circ} \mathrm{C} / \\
75 \% \mathrm{RH}\end{array}$ & $\begin{array}{l}40^{\circ} \mathrm{C} / \\
75 \% \mathrm{RH}\end{array}$ \\
\hline Ivabradine $\mathrm{HCl}$ & .. & $\mathrm{v}$ & $\mathrm{v}$ & $\mathrm{v}$ & $\mathrm{v}$ \\
\hline Ivabradine $\mathrm{HCl}+$ Guar gum & 1:1 & $\mathrm{v}$ & $\mathrm{V}$ & $\mathrm{v}$ & $\mathrm{v}$ \\
\hline Ivabradine $\mathrm{HCl}+$ chitosan & 1:1 & $\mathrm{v}$ & $\mathrm{v}$ & $\mathrm{v}$ & $\mathrm{v}$ \\
\hline Ivabradine $\mathrm{HCl}+$ Pectin & 1:1 & $\mathrm{V}$ & $\mathrm{V}$ & $\mathrm{V}$ & $\mathrm{V}$ \\
\hline Ivabradine $\mathrm{HCl}+$ ethylcellulose & 1:1 & $\mathrm{v}$ & $\mathrm{v}$ & $\mathrm{v}$ & $\mathrm{v}$ \\
\hline Ivabradine $\mathrm{HCl}+$ Magnesium stearate & 1:1 & $\mathrm{v}$ & $\mathrm{v}$ & $\mathrm{V}$ & $\mathrm{v}$ \\
\hline
\end{tabular}


The physical observation of drug and mixtures shows no change in their physical properties. This is revealed that there is no significant interaction between the drug and polymers. The results were present in the Table 5

\subsection{Drug-polymer interaction studies by FTIR}

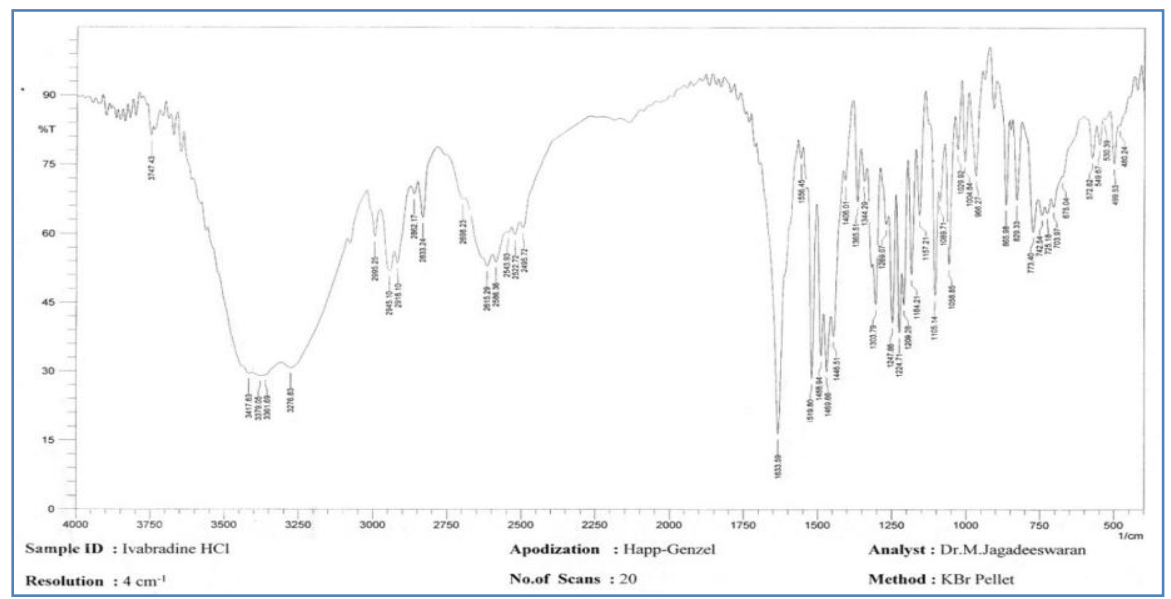

Figure 1: Fourier transform infrared spectroscopy spectrum of Ivabradine Hydrochloride

\subsection{Construction of calibration curve for Ivabradine $\mathrm{HCl}$}

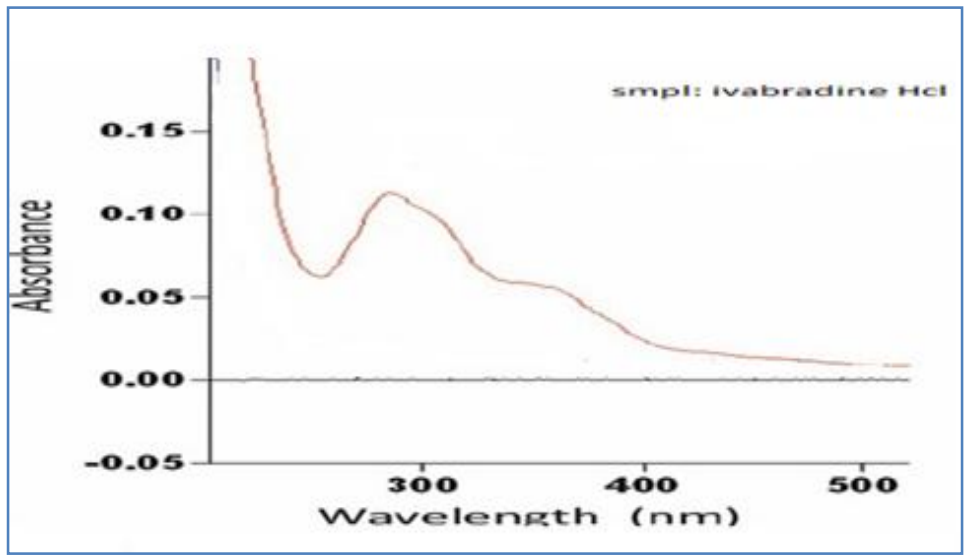

Determination of the lambda maximum

Figure 2: UV spectra Lambda maximum of Ivabradine $\mathrm{HCl}$

Table 6: Calibration Curve of ivabradine $\mathrm{HCl}$

\begin{tabular}{|l|l|}
\hline Concentration $(\mu \mathrm{g} / \mathrm{ml})$ & Absorbance at $285 \mathrm{~nm}$ \\
\hline 0 & 0 \\
\hline 5 & 0.082 \\
\hline 10 & 0.164 \\
\hline 20 & 0.328 \\
\hline 30 & 0.492 \\
\hline 40 & 0.656 \\
\hline 50 & 0.812 \\
\hline
\end{tabular}




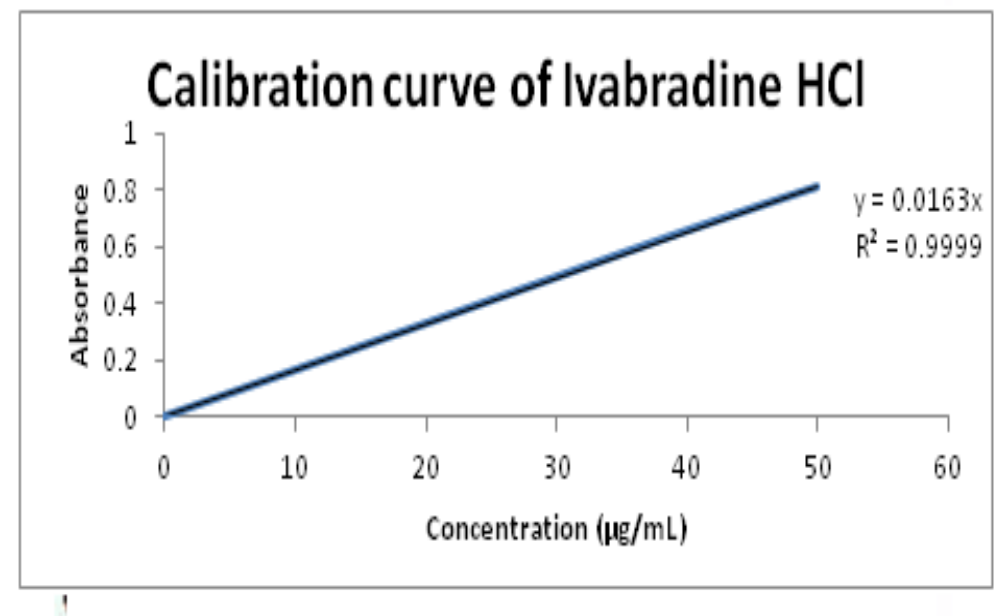

Figure 3: Calibration Curve for ivabradine $\mathrm{HCl}$

4.3.2 Evaluation of pre-compression parameters of sustained release mucoadhesive buccal tablet blends of ivabradine $\mathrm{HCl}$

Table 7: Micrometric properties of Ivabradine HCl tablet blends

\begin{tabular}{|c|c|c|c|c|c|}
\hline \multirow{2}{*}{$\begin{array}{l}\text { Formula } \\
\text { tion } \\
\text { Code }\end{array}$} & \multicolumn{2}{|c|}{$\begin{array}{l}\text { Derived properties Mean } \pm \text { SD } \\
(\mathrm{n}=3)\end{array}$} & \multicolumn{3}{|c|}{ Flow properties Mean \pm SD $(n=3)$} \\
\hline & $\begin{array}{l}\text { Bulk } \\
\text { Density }(\mathrm{g} / \mathrm{cc})\end{array}$ & $\begin{array}{l}\text { Tapped } \\
\text { Density } \\
(\mathrm{g} / \mathrm{cc})\end{array}$ & $\begin{array}{l}\text { Angle of repose } \\
\left({ }^{\circ}\right)\end{array}$ & $\begin{array}{l}\text { Carr's index } \\
(\%)\end{array}$ & $\begin{array}{l}\text { Hausner's ratio } \\
(\%)\end{array}$ \\
\hline $\mathrm{F} 1$ & $0.32 \pm 0.02$ & $0.356 \pm 0.01$ & $27.13 \pm 0.32$ & $09.34 \pm 0.10$ & $1.18 \pm 0.07$ \\
\hline $\mathrm{F} 2$ & $0.34 \pm 0.01$ & $0.350 \pm 0.01$ & $28.36 \pm 0.15$ & $02.82 \pm 0.05$ & $1.15 \pm 0.14$ \\
\hline F3 & $0.30 \pm 0.01$ & $0.346 \pm 0.01$ & $27.53 \pm 0.55$ & $13.44 \pm 0.01$ & $1.13 \pm 0.01$ \\
\hline $\mathrm{F} 4$ & $0.32 \pm 0.01$ & $0.326 \pm 0.02$ & $30.13 \pm 0.95$ & $02.12 \pm 0.09$ & $1.02 \pm 0.05$ \\
\hline F5 & $0.32 \pm 0.01$ & $0.343 \pm 0.02$ & $28.13 \pm 0.25$ & $06.78 \pm 0.01$ & $1.25 \pm 0.30$ \\
\hline F6 & $0.33 \pm 0.01$ & $0.350 \pm 0.01$ & $27.66 \pm 0.68$ & $03.79 \pm 0.01$ & $1.13 \pm 0.09$ \\
\hline F7 & $0.32 \pm 0.02$ & $0.360 \pm 0.01$ & $27.83 \pm 0.20$ & $11.40 \pm 0.57$ & $1.15 \pm 0.04$ \\
\hline F8 & $0.32 \pm 0.05$ & $0.340 \pm 0.01$ & $28.46 \pm 0.40$ & $04.12 \pm 0.32$ & $1.14 \pm 0.09$ \\
\hline
\end{tabular}

\subsubsection{Post compression evaluations of ivabradine $\mathrm{HCl}$ buccal tablets}

Table 8:

\begin{tabular}{|l|l|l|l|l|l|}
\hline $\begin{array}{l}\text { Formulat } \\
\text { ion code }\end{array}$ & $\begin{array}{l}\text { Thickness } \\
(\mathrm{mm})\end{array}$ & $\begin{array}{l}\text { Hardness } \\
\left(\mathrm{Kg} / \mathrm{cm}^{2}\right)\end{array}$ & Friability $(\%)$ & $\begin{array}{l}\text { Drug content } \\
(\%)\end{array}$ & Surface $\mathrm{pH}$ \\
\hline F1 & $5.83 \pm 0.57$ & $3.2 \pm 0.73$ & $0.89 \pm 0.75$ & $94.42 \pm 0.55$ & $6.53 \pm 0.18$ \\
\hline F2 & $6.13 \pm 1.52$ & $3.5 \pm 0.75$ & $0.99 \pm 0.15$ & $96.75 \pm 1.07$ & $6.71 \pm 0.48$ \\
\hline F3 & $6.21 \pm 0.70$ & $3.8 \pm 0.51$ & $0.31 \pm 0.40$ & $98.82 \pm 0.98$ & $6.62 \pm 0.41$ \\
\hline F4 & $5.85 \pm 0.60$ & $3.9 \pm 0.40$ & $0.28 \pm 0.94$ & $90.86 \pm 0.99$ & $6.49 \pm 0.47$ \\
\hline F5 & $5.86 \pm 0.56$ & $4.1 \pm 1.05$ & $0.58 \pm 0.52$ & $92.59 \pm 0.34$ & $6.79 \pm 0.68$ \\
\hline F6 & $6.03 \pm 0.70$ & $4.0 \pm 0.75$ & $0.23 \pm 0.80$ & $94.89 \pm 0.22$ & $6.44 \pm 0.85$ \\
\hline F7 & $6.02 \pm 0.40$ & $3.2 \pm 0.50$ & $0.82 \pm 0.92$ & $94.76 \pm 0.33$ & $6.76 \pm 2.14$ \\
\hline F8 & $6.23 \pm 0.17$ & $3.8 \pm 0.86$ & $0.71 \pm 0.79$ & $99.98 \pm 0.16$ & $6.78 \pm 0.91$ \\
\hline \multicolumn{5}{|l|}{ Mean \pm SD $(\mathrm{n}=3)$} &
\end{tabular}


Manoj Premi et al, Journal of Biomedical and Pharmaceutical Research

\subsubsection{Swelling performance of mucoadhesive buccal tablets}

Table 9:

\begin{tabular}{|l|l|l|l|l|l|}
\hline \multirow{2}{*}{$\begin{array}{l}\text { Formulation } \\
\text { code }\end{array}$} & \multicolumn{5}{|l|}{ Swelling index (Mean \pm SD) } \\
\cline { 2 - 6 } & \multicolumn{5}{|l|}{ Time in hrs } \\
\cline { 2 - 6 } & 1 & 2 & 3 & 4 & 5 \\
\hline F1 & $17.41 \pm 0.32$ & $21.41 \pm 0.59$ & $23.43 \pm 0.53$ & $26.14 \pm 0.67$ & $27.18 \pm 0.69$ \\
\hline F2 & $31.08 \pm 1.10$ & $32.88 \pm 0.29$ & $35.03 \pm 1.72$ & $35.03 \pm 1.06$ & $36.36 \pm 0.75$ \\
\hline F3 & $17.82 \pm 0.62$ & $21.87 \pm 0.40$ & $25.43 \pm 0.62$ & $28.63 \pm 0.49$ & $29.46 \pm 0.36$ \\
\hline F4 & $25.62 \pm 0.53$ & $27.92 \pm 0.37$ & $29.56 \pm 0.40$ & $32.11 \pm 0.36$ & $32.71 \pm 0.70$ \\
\hline F5 & $19.63 \pm 0.44$ & $20.12 \pm 0.66$ & $24.14 \pm 0.86$ & $26.92 \pm 0.33$ & $27.46 \pm 0.29$ \\
\hline F6 & $15.82 \pm 0.37$ & $18.03 \pm 0.70$ & $23.76 \pm 0.34$ & $24.38 \pm 0.41$ & $26.66 \pm 0.25$ \\
\hline F7 & $16.42 \pm 0.44$ & $19.40 \pm 0.37$ & $24.64 \pm 0.36$ & $24.79 \pm 025$ & $30.43 \pm 054$ \\
\hline F8 & $15.19 \pm 0.17$ & $16.32 \pm 0.17$ & $22.43 \pm 0.35$ & $24.29 \pm 0.27$ & $27.39 \pm 0.21$ \\
\hline
\end{tabular}

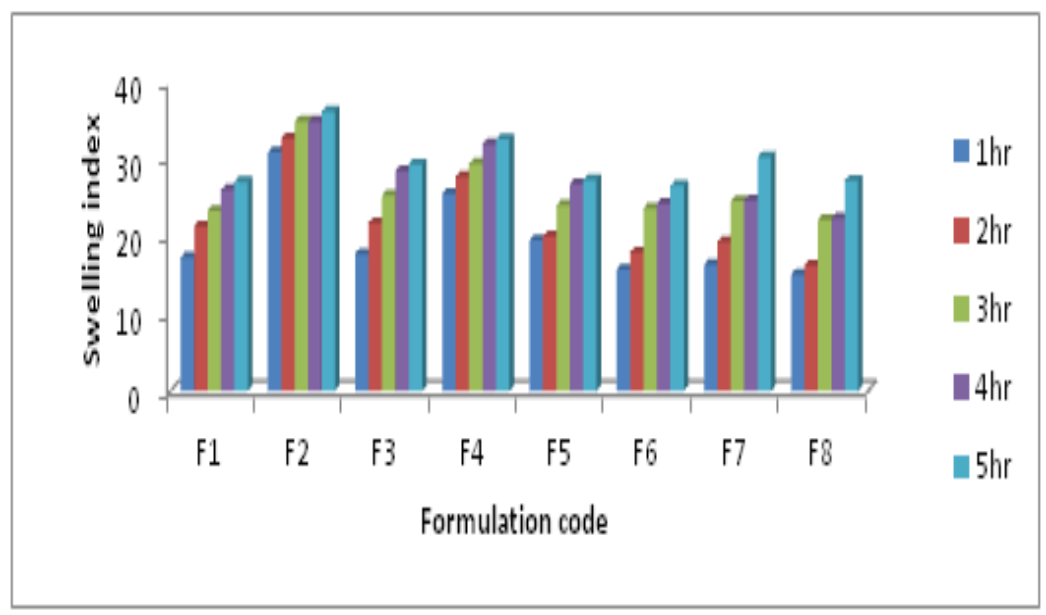

Figure 5: displays the diagram of swelling index of formulations with respect to time

\section{Effect of formulation variables on mucoadhesive strength}

Table 10: Mucoadhesive strength of buccal tablets

\begin{tabular}{|l|l|}
\hline Formulation Code & $\begin{array}{l}\text { Mucoadhesive Strength(g) } \\
\text { (Mean } \pm \text { SD) }\end{array}$ \\
\hline F1 & $37.43 \pm 0.40$ \\
\hline F2 & $50.27 \pm 0.25$ \\
\hline F3 & $40.33 \pm 0.35$ \\
\hline F4 & $40.53 \pm 0.25$ \\
\hline F5 & $45.33 \pm 0.35$ \\
\hline F6 & $40.43 \pm 0.40$ \\
\hline F7 & $35.43 \pm 0.45$ \\
\hline F8 & $35.26 \pm 0.30$ \\
\hline
\end{tabular}

\subsubsection{In vitro permeation studies of sheep buccal mucosa}

The Modified Franz diffusion apparatus was used for the in vitro permeation studies. Excised sheep buccal mucosa was employed for the permeation studies. The quantity of drug that permeates through the sheep buccal mucosa at distinct intervals in a phase of 4 hours was determined spectrophotometrically at $285 \mathrm{~nm}$. 
Manoj Premi et al, Journal of Biomedical and Pharmaceutical Research

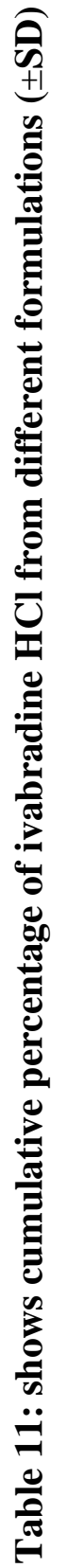

\begin{tabular}{|c|c|c|c|c|c|c|c|c|c|}
\hline \multirow{8}{*}{ 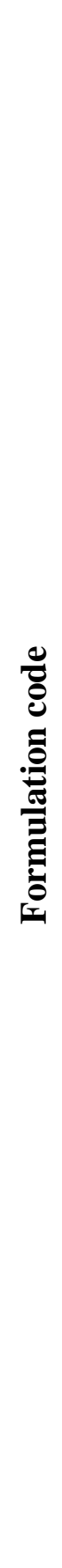 } & $\infty$ & 0 & 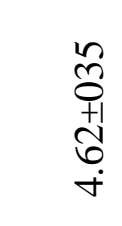 & 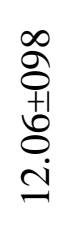 & 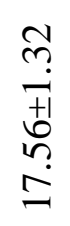 & 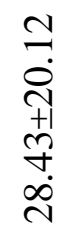 & $\begin{array}{c}\hat{\sigma} \\
\underset{+1}{+1} \\
\infty \\
\dot{\sigma}\end{array}$ & 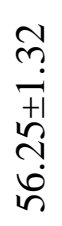 & $\begin{array}{l}\hat{\infty} \\
\stackrel{.}{+1} \\
\\
\alpha \\
\infty \\
0\end{array}$ \\
\hline & 空 & $\theta$ & 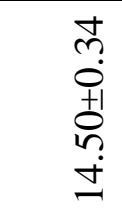 & 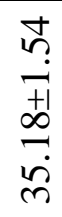 & 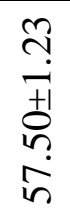 & $\frac{\widetilde{\sigma}}{\dot{\sigma}}$ & 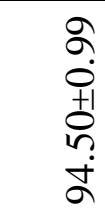 & & \\
\hline & to & $\theta$ & 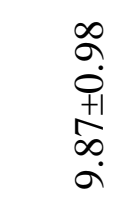 & 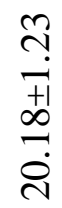 & $\begin{array}{l}8 \\
\stackrel{8}{+1} \\
+1 \\
\stackrel{\infty}{\dot{m}}\end{array}$ & 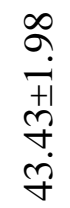 & in $\begin{array}{c}\hat{0} \\
0 \\
0 \\
\text { iे } \\
\text { in }\end{array}$ & 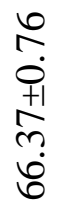 & 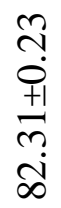 \\
\hline & 10 & $\theta$ & \begin{tabular}{l}
$n$ \\
\multirow{0}{0}{} \\
+1 \\
8 \\
0
\end{tabular} & 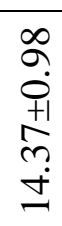 & 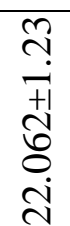 & $\begin{array}{l}\Omega \\
\vdots \\
0 \\
+1 \\
\\
0 \\
0\end{array}$ & $\begin{array}{l}\infty \\
0 \\
0 \\
+1 \\
\infty \\
0 \\
\infty \\
\infty\end{array}$ & 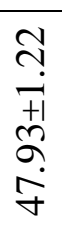 & 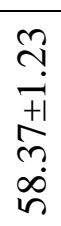 \\
\hline & I & $\theta$ & $\begin{array}{l}\infty \\
0 \\
0 \\
+1 \\
\infty \\
0 \\
\dot{n} \\
\dot{0}\end{array}$ & 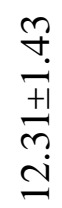 & 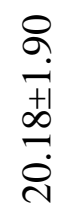 & $\begin{array}{l}8 \\
\infty \\
0 \\
+1 \\
8 \\
8\end{array}$ & $\begin{array}{l}\infty \\
\dot{0} \\
+1 \\
\infty \\
\infty \\
0 \\
0\end{array}$ & $\begin{array}{l}\bar{n} \\
0 \\
+1 \\
m \\
\stackrel{+}{*}\end{array}$ & 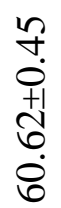 \\
\hline & வ & $\theta$ & $\begin{array}{l}\text { त̂ } \\
0 \\
+1 \\
0 \\
0 \\
0\end{array}$ & 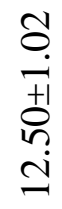 & 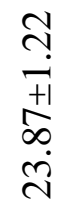 & 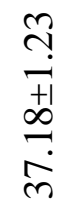 & 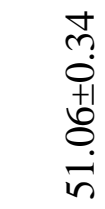 & $\begin{array}{l}\text { के } \\
\dot{0} \\
+1 \\
0 \\
\\
\dot{0}\end{array}$ & 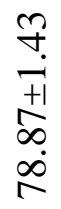 \\
\hline & $\widetilde{N}$ & 0 & $\begin{array}{l}8 \\
0 \\
0 \\
+1 \\
0 \\
0 \\
i\end{array}$ & 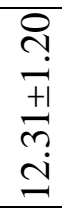 & 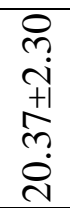 & $\begin{array}{l}\stackrel{0}{n} \\
\stackrel{+1}{+1} \\
\stackrel{n}{n} \\
0 \\
\stackrel{n}{n}\end{array}$ & 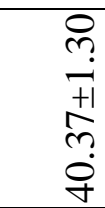 & $\begin{array}{l}\stackrel{P}{+} . \\
\dot{+1} \\
\infty \\
\infty \\
\dot{n}\end{array}$ & 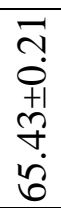 \\
\hline & 厌 & $\theta$ & $\begin{array}{l}\vec{\sim} \\
\stackrel{+}{+} \\
\stackrel{1}{\sim} \\
\stackrel{+}{+}\end{array}$ & $\begin{array}{l}\text { त̂ } \\
\text { ô } \\
+11 \\
0 \\
\stackrel{0}{0}\end{array}$ & 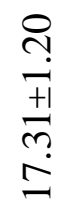 & 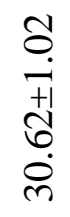 & 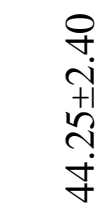 & $\begin{array}{l}\stackrel{0}{n} \\
+1 \\
\text { in } \\
\stackrel{+}{0}\end{array}$ & $\begin{array}{l}0 \\
\frac{n}{41} \\
0 \\
0 \\
\dot{0} \\
\infty\end{array}$ \\
\hline 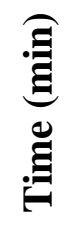 & & $\theta \quad 0$ & లి & 8 & ริ & తิ & 18 & 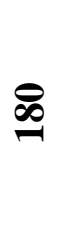 & $\underset{\sim}{\stackrel{P}{N}}$ \\
\hline
\end{tabular}




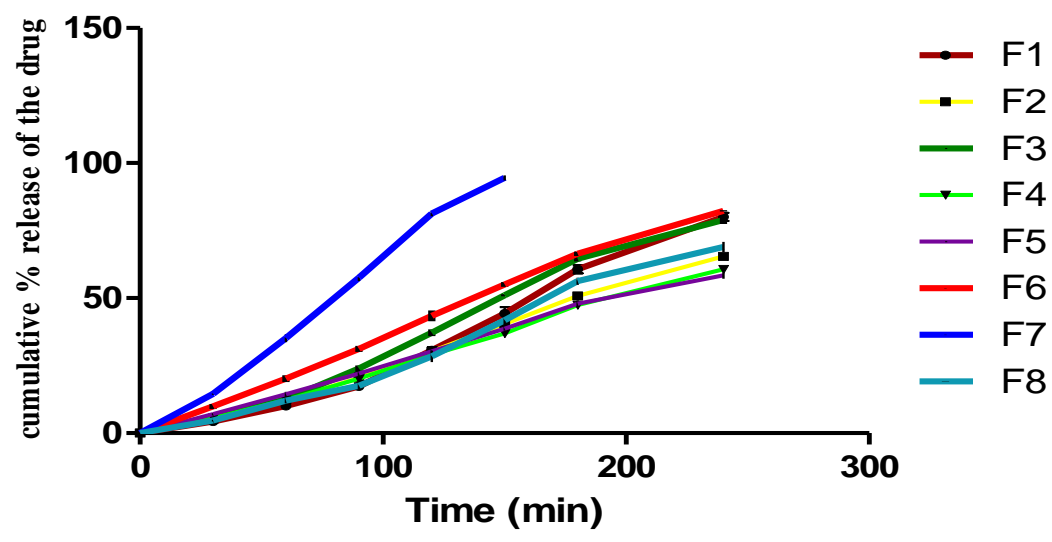

Figure 7: depicts in vitro cumulative percentage drug release of all formulations

Table 12: Release kinetics behavior of different formulations of ivabradine $\mathrm{HCl}$ buccal tablet

\begin{tabular}{|c|c|c|c|c|c|}
\hline \multirow[t]{2}{*}{$\begin{array}{l}\text { Formulation } \\
\text { code }\end{array}$} & \multirow{2}{*}{$\begin{array}{l}\text { Zero- } \\
\text { Order [r] } \\
(\mathrm{Mt} v \mathrm{t}) \\
( \pm \mathrm{SD})\end{array}$} & \multirow{2}{*}{$\begin{array}{l}\text { First- } \\
\text { Order [r] } \\
\log \left(M_{0}-M_{t}\right) \text { vs t } \\
( \pm S D)\end{array}$} & \multirow{2}{*}{$\begin{array}{l}\text { Higuchi- } \\
\text { Matrix[r] } \\
\left(\mathrm{M} \text { vs } \mathrm{t}^{0.5}\right) \\
( \pm \mathrm{SD})\end{array}$} & \multicolumn{2}{|c|}{$\begin{array}{l}\text { Korsmeyer Peppas } \\
\log (M t) \text { vs } \log (t)\end{array}$} \\
\hline & & & & {$[\mathrm{r}]$} & $\mathrm{N}$ \\
\hline F1 & $0.945 \pm 0.033$ & $0.893 \pm 0.020$ & $0.712 \pm 0.014$ & $0.879 \pm 0.002$ & 0.70 \\
\hline $\mathrm{F} 2$ & $0.986 \pm 0.064$ & $0.963 \pm 0.038$ & $0.798 \pm 0.006$ & $0.929 \pm 0.10$ & 0.70 \\
\hline F3 & $0.976 \pm 0.040$ & $0.944 \pm 0.015$ & $0.783 \pm 0.046$ & $0.93 \pm 0.12$ & 0.70 \\
\hline $\mathrm{F} 4$ & $0.992 \pm 0.048$ & $0.972 \pm 0.045$ & $0.816 \pm 0.027$ & $0.946 \pm 0.22$ & 0.69 \\
\hline F5 & $0.995 \pm 0.154$ & $0.987 \pm 0.031$ & $0.858 \pm 0.028$ & $0.971 \pm 0.01$ & 0.70 \\
\hline F6 & $0.996 \pm 0.006$ & $0.956 \pm 0.013$ & $0.862 \pm 0.016$ & $0.984 \pm 0.003$ & 0.70 \\
\hline F7 & $0.992 \pm 0.045$ & $0.885 \pm 0.037$ & $0.862 \pm 0.034$ & $0.989 \pm 0.43$ & 0.88 \\
\hline F8 & $0.963 \pm 0.047$ & $0.939 \pm 0.007$ & $0.754 \pm 0.007$ & $0.908 \pm 0.65$ & 0.69 \\
\hline
\end{tabular}

All values are expressed as Mean \pm SD

\subsubsection{Stability studies of best formulation(F2)}

Table 13:

\begin{tabular}{|l|l|l|l|}
\hline Parametrers & After 30 days & After 60 days & After 90 days \\
\hline $\begin{array}{l}\text { Physical } \\
\text { appearance }\end{array}$ & No changes & No changes & No changes \\
\hline $\begin{array}{l}\text { Swelling index } \\
\text { (at end } \text { th }^{\text {hr })}\end{array}$ & $37.3 \pm 0.15$ & $38.63 \pm 1.32$ & $37.22 \pm 0.25$ \\
\hline $\begin{array}{l}\text { Buccoadhesive } \\
\text { strength }\end{array}$ & $49.92 \pm 0.34$ & $51.72 \pm 0.35$ & $51.01 \pm 1.33$ \\
\hline Hardness & $3.7 \pm 0.55$ & $3.8 \pm 0.23$ & $3.2 \pm 0.12$ \\
\hline
\end{tabular}

Short term stability study of the optimized ivabradine $\mathrm{HCl}$ buccal tablets, the obtained results reflect that there is no significant change such as physical appearance, and their mucoadhesive strength, swelling index and invitro drug release, suggesting the satisfactory stability of the buccal tablets.

\section{SUMMARY AND CONCLUSION:}

An antianginal drug ivabradine $\mathrm{HCl}$ which has poor oral bio-availability and lesser biological plasma half life, hence an attempt was made to prepare mucoadhesive buccal tablets of ivabradine $\mathrm{HCl}$ in order to enhance the bioavailability and sustain its release by utilizing natural biodegradable polymers like guar gum pectin and chitosan incorporated in 
the formulations to attain a buccal sustained release of the ivabradine $\mathrm{HCl}$.

Physiochemical properties studies like precompression, UV analysis and compatibility study of ivabradine $\mathrm{HCl}$ was complied with standard.

The following parameters were selected during evaluation:

All the prepared formulations were subjected for evaluations like post compression studies, surface $\mathrm{pH}$ of tablets, mucoadhesive strength, and ex-vivo drug permeation through sheep buccal mucosa, release kinetics, and stability study have shown satisfactory results.

The FTIR spectra shown that, there was no chemical interaction between polymers and ivabradine $\mathrm{HCl}$.

In-vitro drug release of the formulation of ivabradine $\mathrm{HCl}$ tablet which was prepared with guar gum, pectin and chitosan (F2) with high level concentration guar gum and least level concentration of pectin and chitosan was showed maximum sustained release (10 hr), depicted in figures no 7.5.

The drug release kinetic study indicated that the release data was best fitted with zero order, and Kormeyer peppas model shown in figure no 7 . Which explains the anomalous diffusion mechanism or non-Fickian of drug release through buccal tablets.

The short term stability study result confirms that no appreciable changes in physical appearance, swelling index, drug content, bucco-adhesive strength and in-vitro drug release profile obtained. Hence formulations were found to be stable under the conditions used for the stability studies.

\section{CONCLUSION}

Mucoadhesive buccal tablet of ivabradine $\mathrm{HCl}$ were successfully prepared by direct compression method presented herein based on the natural polymers blend hold promise for oral administration of ivabradine $\mathrm{HCl}$ and also found to be simple and reproducible.
The polymers guar gum, pectin and chitosan are used as carrier and also easily available and biocompatibility.

$\mathrm{F} 1$ and $\mathrm{F} 5$ possessed the best results among all the formulations in terms of in vitro release of drug. However, F2 formulation shows highest mucoadhesive and swelling index than other formulation. Therefore, from the data, it may be concluded that F2 formulation might be considered as promising mucoadhesive buccal tablet formulation for a suitable sustained drug delivery system for ivabradine.

\section{REFERENCES:}

1. Joseph, A.; and DiMasi. "The price of innovation: new estimates of drug development costs" Journal of Health Economics.22, 2003, 151-185.

2. Felipe; Varum, J.O; Emma.; Connell L.M.C.; Joao.; Francisco.; Veiga.; Basit.; and Abdul,W. "Mucoadhesion and the Gastrointestinal Tract". .Critical reviews in Therapeutic Drug carrier System. 25, 2008, 207-258.

3. Janet, A.J.; Hoogstraate.; and Philip W Wertz. "Drug delivery via the buccal mucosa". Pharmaceutical Science \& Technology Today. 1(7), 1998, 309-316

4. Gavin P Andrews.; Thomas P Laverty.; and David $S$ Jones. "Mucoadhesive polymeric platforms for controlled drug delivery".Eur J Pharm Biopharm. 71, 2009, 505-518.

5. Vyas, S.P.; and khar. R.K.; "Controlled drug delivery- concepts and advances". Vallabh prakashan publications, $1^{\text {st }}$ ed. New Delhi, 2002.

6. Khairnar, G.A.; sayyad F.J. "Development of Buccal Drug DeliverySystems Based on Mucuadhesive Polymers". Int I Pharm Tech Res. 2(1), 2010, 719-735.

7. Marcos Luciano Bruschi, Osvaldo de Freitals. "Oral Bioadhesive Drug Delivery Systems" Drug Development and Industrial Pharmacy. 31(3), 2005, 293-310.

8. Longer, M.A.; Robinson, J.R.; "Fundamental Aspects of Bioadhesion". Pharm Int. 7, 1986, 114- 117. 
9. Andrews, G.P, Laverty T.P, Jones DS. "Mucoadhesive polymeric platforms for controlled drug delivery" Eur J Pharm Biopharm. 71(3), 2009, 505-518.

10. Kulkarni, et. al. "Gums and Mucilages Therapeutic and Pharmaceutical Applications" Natural Product radine. 1(3), 2002, 10-17.

11. Sinha VR, Rachna K. "Polysaccharides in colon-specific drug delivery" Int J Pharm. 224(1-2),2001.; 19-38.

12. Patel Dhara $B$, Patel Madhabhai $M$. "Natural excipients in controlled drug delivery systems" J Pharm Res. 2009; 2(5):900-907.

13. Venkata R.E. "Chemical and biological aspects of selected polysaccharides" Indian J Pharm Sci. 54, 1992, 90-97.

14. Hannah Batchelor et. al. "Novel bioadhesive formulations in drug delivery" The drug delivery companies report, Autumn/winter.2004,16-19.

15. Chaitanya Kumar Y, et.al."Formulation and Evaluation of Mucoadhesive Buccal Tablets of Captopri"IInternational Journal of Pharma and Chemical Research 2017; 3(3):662-686.

16. Deepak Karki et. al. "Formulation and Evaluation of Mucoadhesive Buccal Tablets of Curcumin and its Bioavailability Study" Research J. Pharm. and Tech 2017; 10(12): 4121-4128.

17. Sandhya $P$ et. al. "Formulation and evaluation of mucoadhesive buccal tablets of losartan by using natural polymers" Int. J. of Pharmacy and Analytical Research 2016;5(2):239-244.

18. Chen, Y.S.; Squier, C.A.; "The ultrastructure of the oral epithelium". In: Meyer, J.; Squier, C.A.; Gerson, S.J.; The structure and function of oral mucosa. Pergamon Press, Oxford, 1984, 7-30.

19. Harris, D.; Robinson, J.R. “Drug delivery via the mucous membranes of the oral cavity".J Pharm Sci. 81, 1992, 1-10.
20. Gandhi, R.B.; Robinson, J.R.; "Oral cavity as a site for bioadhesive drug delivery". Adv Drug Deliv Rev. 13, 1994, 43-74.

21. Stablein, M.J, Meyer, J.; "The vascular system and blood supply". The structure and function of oral mucosa, Pergamon Press, Oxford. 1984, 237-56.

22. Galey, W.R.; Lonsdale, H.K.; Nacht, S. J "The in vitro permeability of skin and buccal mucosa to selected drugs and tritiated water".Invest Dermatol. 67, 1976, 713-717.

23. Slomiany, B.L.; Murthy, V.L.N.; Piotrowski, J.; Slomiany, A. "Salivary mucins in oral mucosal defenseGen Pharmacol" The Vascular system. 27(5), 1996, 761-771.

24. Rathbone, M. J.; Hadgraft, J. "Absorption of drugs from the human oral cavity". Int J Pharm. 74, 1991, 9-24.

25. Kavita Khanivilkar.; Maureen D Donovan.; Douglas R Flanagan.; Advanced Drug Delivery Reviews. 48, 2001,173-193.

26. John D. Smart, "Lectin-mediated drug delivery in the oral cavity", Advanced Drug Delivery Reviews 56, 2004, 481- 489

27. Squier, C.; "Zinc iodide-osmium staining of membrane-coating granules in keratinized and non-keratinized mammalian oral epithelium".Archives of oral Biology. 27, 1982, 377-382.

28. Swartzendruber, D.C.; "Studies of epidermal lipids using electron microscopy",Semin Dermatol. 11, 1992, 157-161.

29. Rama Bansil.; Bradley S Turner.; , "Mucin structure, aggregation, physiological functions and biomedical applications".Current Opinion in Colloid \& Interface Science. 11, 2006, 164-170.

30. Peppas, N.A.; Buri, P.A.; "Surface, interfacial and molecular aspects of polymer bioadhesion on soft tissues."J Control Release. 2, 1985, 257-275. 